УДК 616-084+616-005.6+613.98+616.37-002

DOI 10.11603/2414-4533.2016.4.7182

( ) І. М. ШЕВЧУК, Р. Т. КУЗЕНКО

Івано-Франківський національний медичний університет

\title{
Профілактика венозного тромбоемболізму у хворих старшої вікової групи з гострим некротичним панкреатитом
}

\author{
I. M. SHEVCHUK, R. T. KUZENKO \\ Ivano-Frankivsk National Medical University
}

\section{PREVENTION OF VENOUS THROMBOEMBOLISM IN PATIENTS OF ELDERLY AND SENILE AGE GROUP WITH ACUTE NECROTIZING PANGREATITIS}

\begin{abstract}
Проведено вивчення системи гемостазу у 43 хворих похилого віку на гострий некротичний панкреатит, які перебували на лікуванні в Івано-Франківській обласній клінічній лікарні з 2013 до 2016 року. Чоловіків було 27 (62,7 \%), жінок - 16 (37,2 \%). Вік хворих складав від 60 до 81 року, в середньому $(66,2 \pm 1,18)$ року. В першу добу після госпіталізації лапароскопічні втручання виконано у 36 (83,7 \%) хворих. Лапароскопічне дренування черевної порожнини $з$ причини поширеного ферментативного перитоніту проведено у 27 (62,7 \%) хворих. Лапароскопічну холецистектомію і дренування черевної порожнини при поширеному ферментативному перитоніті виконано у 9 (21 \%) пацієнтів. У 7 (16,2 \%) хворих проведено ранні відкриті операційні втручання.

У 24 (55,8 \%) пацієнтів проводили профілактику тромбоемболічних ускладнень низькомолекулярними гепаринами. Групу порівняння склали 19 (44 \%) хворих, у яких профілактику тромбоемболічних ускладнень не проводили. У пацієнтів похилого віку із гострим некротичним панкреатитом переважали процеси гіперкоагуляції. Застосування низькомолекулярних гепаринів для профілактики тромбогеморагічних ускладнень у хворих похилого віку забезпечувало швидке усунення порушень гемокоагуляції та сприяло поліпшенню показників судинно-тромбоцитарної ланки гемостазу.
\end{abstract}

The study of the system gemostazis in $\mathbf{4 3}$ patients of elderly age with the acute pancreatitis who were treated in Ivano-Frankivsk Regional Clinical Hospital from 2013 to 2016 was conducted. Among them there were 27 men (62.7 \%), and 16 (37.2 \%) women. Age of patients made from 60 to 81 years, on the average $66.2 \pm 1.18$ years. In the first days after hospitalization laparoscopic interventions were performed in $36(83.7 \%)$ patients. Laparoscopic drainage from abdominal cavity due to widespread enzymatic was peritonitis performed in $27(62.7 \%)$ patients. Laparoscopic cholecystectomy and drainage of the abdominal cavity in advanced enzymatic peritonitis was performed in $9(21 \%)$ patients. In $7(16.2 \%)$ patients was conducted completed early laparatomy.

$24(55.8 \%)$ patients underwent prevention of thromboembolic complications. Comparison group consisted of 19 (44 \%) patients in whom the prevention of thromboembolic complications wasn't performed. In elderly patients with acute necrotizing pancreatitis hypercoagulable processes dominated. The use of low molecular weight heparin for the prevention of trombohemoragge complications in elderly patients provided hemocoagulation rapid elimination of violations and contributed to improvements in vascular-platelet hemostasis level.

Постановка проблеми і аналіз останніх досліджень та публікацій. Гострий панкреатит (ГП) - одне $з$ найтяжчих, прогностично несприятливих i часто загрозливих захворювань черевної порожнини. В останні роки відмічають значне зростання захворюваності у хворих похилого віку [1]. Некротичні форми ГП складають близько 14 \%, летальність може сягати 40-70 \%, переважно у хворих, старших 60 років [2]. В патогенезі гострого некротичного панкреатиту (ГНП) велике значення мають порушення внутрішньосудинної коагуляції, викликані пошкодженням ендотелію судин у зоні запалення, погіршенням реологічних властивостей крові, порушенням мікроциркуляції, викидом у системний кровотік надмірної кількості медіаторів запалення та інгібіторів фібринолізу, які підви- щують агрегаційні властивості тромбоцитів [3, 4]. Пошкодження панкреатичної мікроциркуляції з мікротромбозами виникають на початковій стадії ГП у багатьох випадках. Внаслідок цього збільшується ішемічне пошкодження панкреатичної тканини та парапанкреатичної заочеревинної клітковини, тому саме порушення мікроциркуляції на тлі гіперкоагуляції призводять до розвитку некротичних змін [4].

Зважаючи на похилий вік хворих, для яких характерними є переважання процесів гіперкоагуляції, в подальшому це призводить як до блокування мікроциркуляції і погіршення газообміну, так і до зростання ризику венозних тромбоемболічних ускладнень [5, 6, 7].

Перспективним напрямком у покращенні профілактики тромбогеморагічних ускладнень у хво- 
рих похилого віку на ГНП є застосування низькомолекулярних гепаринів (НМГ). Антитромботичний ефект НМГ тривалий час пов’язували виключно 3 анти-Ха-активністю. В останні роки доведено, що тільки 30 \% активності НМГ реалізується через антитромбін III (ATIII), а 70 \% через інгібітор зовнішнього шляху згортання ТFPI. Останній володіє також вираженою антипротеазною активністю за рахунок утворення неактивних комплексів із такими протеолітичними ферментами, як трипсин, плазмін, калікреїн та ін., як в плазмі крові, так і в тканині підшлункової залози $[7,8]$.

Мета роботи: поліпшити діагностику порушень системи гемостазу та дослідити ефект застосування низькомолекулярних гепаринів для профілактики та корекції тромбогеморагічних ускладнень у хворих похилого віку з гострим деструктивним панкреатитом.

Матеріали і методи. Нами обстежено 43 хворих похилого віку на ГНП, які перебували на лікуванні в Івано-Франківській обласній клінічній лікарні з 2013 до 2016 року. Чоловіків було 27 (62,7 \%), жінок - 16 (37,2 \%). Вік хворих складав від 60 до 81 року, в середньому $(66,2 \pm 1,18)$ року.

Діагноз ГНП підтверджували клінічними, лабораторними та інструментальними методами дослідження (ЕФГДС, УЗД, КТ, лапароскопія). Прогнозування тяжкості ГП визначали при наявності трьох та більше критеріїв Ranson і 8 балів за шкалою АРАСНЕ II, або при розвитку органної недостатності: легеневої, ниркової, шоку. При підтвердженні тяжкого ГП комплексне лікування хворих з моменту госпіталізації в стаціонар проводили в умовах відділення реанімації та інтенсивної терапії. Для адекватної інфузійної терапії, відновлення електролітних порушень, парентерального харчування та контролю центрального венозного тиску всім хворим із тяжким ГП встановлювали центральний венозний катетер. 3 метою знеболювання, відновлення перистальтики і поліпшення спланхнічного кровотоку всім хворим із тяжким ГП проводили пролонговану епідуральну аналгезію. Специфічна терапія хворих із тяжким ГП включала фармакологічну інгібіцію екзокринної секреції підшлункової залози за допомогою синтетичних аналогів соматостатину.

У першу добу після госпіталізації лапароскопічні втручання виконано у 36 (83,7 \%) хворих. Лапароскопічне дренування черевної порожнини 3 причини поширеного ферментативного перитоніту проведено у 27 (62,7 \%) хворих. Лапароскопічну холецистектомію і дренування черевної порожнини при поширеному ферментативному перитоніті виконано у 9 (21 \%) хворих. У 7 (16,2%) хворих через поширеність гнійно-некротичного процесу в підшлунковій залозі, гнійний парапанкреатит, наявність вільних секвестрів, поширені двобічні заочеревинні флегмони виконано ранні відкриті операційні втручання.

У 24 (55,8 \%) хворих проводили профілактику тромбоемболічних ускладнень низькомолекулярними гепаринами. Препарат вводили в дозі 0,1 мл на 10 кг маси тіла на добу, підшкірно, починаючи з 2-ї доби після операції впродовж 7 днів. Групу порівняння склали 19 (44%) хворих, у яких профілактику тромбоемболічних ускладнень не проводили. Групи хворих зіставні за характером основного захворювання, віком, статтю, обсягом і часом проведених операційних втручань.

Стан системи згортання крові досліджували 3 використанням методів, що характеризують основні ланки системи гемостазу:

- тромбопластиновий час за методикою R. M. Biggs i R. G. Makfartane (1962);

- фібриноген - гравіметричним методом за Р. А. Рутбергом (1964);

- показники активності XIII фактора згортання крові, параметри агрегації тромбоцитів, продукти деградації фібрину, активність IV фактора тромбоцитів - за допомогою реактивів наукововиробничої фірми “SIMKO Ltd” (Львів).

Забір крові проводили відразу після госпіталізації хворих у відділення, а також на 3-тю та 7-му добу. Математичну обробку результатів дослідження здійснювали за допомогою програм Microsoft Excel та Microsoft Access.

\section{Результати досліджень та їх обговорення.}

У хворих основної групи і групи порівняння рівень АЧТЧ на час госпіталізації складав у середньому $(36,05+1,02)$ с.

У 24 хворих основної групи на фоні застосування НМГ були відмічені зміни активованого часткового тромбопластинового часу (АЧТЧ), показника, який відображає процеси згортання крові за внутрішнім механізмом. На 3-й день лікування НМГ у хворих основної групи АЧТЧ складав $(43,65 \pm 0,92)$ с, що констатувало зростання показника на 83 \% за відношенням до вихідного рівня. На 7-й день лікування в зазначеній групі хворих АЧТЧ становив $(47,17 \pm 0,98)$ с $(\mathrm{p}<0,001)$.

У групі порівняння АЧТЧ на 3-й день складав $(27,54 \pm 1,03)$ с, на 7-й - $(29,50 \pm 1,54)$ с за відношенням до вихідного рівня. Вказане свідчило про переважання процесів гіперкоагуляції у хворих похилого віку на ГНП у групі порівняння, яке було більш вираженим на 3-тю добу дослідження.

В основній групі хворих під впливом низькомолекулярних гепаринів найбільш істотні зміни відмічено у функціональній активності тромбоци- 


\section{З ДОСВІДУ РОБОТИ}

тів, що можна пояснити опосередкованим впливом антикоагулянтів на судинно-тромбоцитарний гемостаз. Порівняно з показниками хворих із групи порівняння функціональна активність тромбоцитів у 20 (83,3 \%) хворих основної групи вже через 7 днів від початку лікування НМГ характеризувалася достовірним подовженням скорочених хронометричних параметрів агрегації тромбоцитів. Зокрема, латентного періоду агрегації тромбоцитів - на 18,6 \%, часу агрегації - на 14,0 \%, зниження ступеня агрегації - на 11,8 \% (p<0,05) порівняно з вихідними показниками. Про зниження інтенсивності утворення внутрішньосудинних тромбоцитарних агрегатів свідчило також зменшення активності IV фактора тромбоцитів у 2 рази.

У 24 хворих (55,8 \%), яким для профілактики післяопераційних тромбогеморагічних ускладнень застосували НМГ, відмічали зниження рівня продуктів деградації фібрину при нормалізації фібринолітичної активності крові до 7 діб. У 19 хворих (44%), яким не призначали НМГ, цих змін не відмічали.

Рівень фібриногену, який виробляється паренхіматозними клітинами печінки в плазмі крові у хворих основної групи, суттєво не відрізнявся від показників норми і на час госпіталізації становив у середньому $(3,52 \pm 2,12)$ г/л.

У хворих групи порівняння цей показник на час госпіталізації складав $(2,23+2,13)$ г/л відносно норми $(p<0,05)$. Вказане $\epsilon$ характерним для зниження білковосинтезуючої функції печінки.

Показники активності XIII фактора згортання крові (фібринази), фермента, який бере безпосередню участь в утворенні фібринового згортка, у хворих основної групи та групи порівняння на 1-шу добу після операції майже не відрізнялись та відповідали показникам норми (p>0,05). Проте цей показник у хворих групи порівняння на 3-тю добу зростав до 15,8 \%, на 7-му добу - до 18,6 \% порівняно з вихідним рівнем у даній групі. Збільшення цього показ-

\section{СПИСОК ЛІТЕРАТУРИ}

1. Березницький Я. С. Результати лікування пацієнтів з гострим панкреатитом в умовах багатопрофільного хірургічного стаціонару / Я. С. Березницький, Р. В. Дука // Зб. наук. пр. співробіт. НМАПО імені П. Л. Шупика. - 2014. - № 23 (2). C. 54-61.

2. Особенности патогенетического подхода к лечению острого некротического панкреатита / О. И. Дронов, И. А. Ковальская, В. Ю. Горлач [и др.] // Укр. журн. хірургії. - 2013. № 3 (22). - С. 145-148.

3. Дацюк О. І. Корекція ендотеліальної дисфункції та дисцитокінемії у хворих за тяжкого гострого панкреатиту при проведенні ранньої рідинної ресусцитації / О. І. Дацюк // Клінічна хірургія. - 2016. - № 6. - С. 24-27.

4. Суханов Г. А. Профилактика тромбоэмболических осложнений у лиц среднего и пожилого возраста / Г. А. Суха- ника свідчить про зниження активності фібринази, що є передумовою процесів гіперкоагуляції.

Аналіз отриманих даних свідчить, що у хворих, яким не проводили профілактику тромбогеморагічних ускладнень НМГ, зростає загальний потенціал гемокоагуляції внаслідок збільшення інтенсивності тромбогенезу за зовнішнім та внутрішнім шляхами активації, активації тромбоцитарної ланки первинного гемостазу та зниження антикоагулянтного потенціалу.

Як показали наші дослідження, НМГ має високу клінічну ефективність, володіє не тільки антитромботичним ефектом, але і вираженою антиферментативною активністю, позитивним реологічним і метаболічним впливом на тканинному і системному рівнях.

Таким чином, застосування НМГ для профілактики післяопераційних тромбогеморагічних ускладнень у хворих похилого віку на ГНП сприяє поліпшенню показників коагуляційного гемостазу, зниженню рівня агрегації тромбоцитів, продукції деградації фібрину та нормалізації активованого часткового тромбопластинового часу.

Зручність та простота застосування НМГ, відсутність виражених побічних ефектів і потреби частого лабораторного моніторингу роблять їх препаратами вибору в профілактиці тромбогеморагічних ускладнень у хворих похилого віку на гострий некротичний панкреатит.

Висновки. 1. У хворих похилого віку із гострим некротичним панкреатитом характерним $€$ переважання процесів гіперкоагуляції та активації судинно-тромбоцитарного гемостазу.

2. Застосування низькомолекулярних гепаринів як засобу профілактики післяопераційних тромбогеморагічних ускладнень у хворих похилого віку на гострий некротичний панкреатит забезпечує швидке усунення порушень коагуляційного гемостазу та сприяє поліпшенню показників судинно-тромбоцитарної ланки гемостазу.

нов, В. Е. Рудакова, С. А. Васильев // Клиническая геронтология. - 2007. - № 4. - С. 10-15.

5. Применение фраксипарина в комплексном лечении деструктивного панкреатита / И. Е. Верхулецкий, О. В. Розенко, В. В. Волков [и др.] // Експериментальна і клінічна хірургія. - 2004. - № 3. - С. 30-31.

6. Низкомолекулярные гепарины в анестезиологии и интенсивной терапии / Л. В. Усенко, С. В. Срибнюк, В. И. Слива [и др.]. - Днепропетровск, 2001. - 41 с.

7. American college of Gastroenterology guidline management of acute pancreatitis / S. Tenner, J. Baillie, J. DeWitt [et al.] // Am. J. Gastroenterol. - 2013. - Vol. 108. - P. 1400-1415.

8. Liao J. K. Linking endothelial dysfunction with endothelial cell activation / J. K. Liao // J. Clin. Invest. - 2013. - Vol. 123, № 2. - P. 540-541.

Отримано 03.11.16 